\title{
The Ageing Scottish Population: Trends, Consequences, Responses
}

\author{
Robert Raeside \\ Napier University \\ r.raeside@napier.ac.uk
}

Hafiz T.A. Khan

Oxford Institute of Ageing

hafiz.khan@ageing.ox.ac.uk

\begin{abstract}
The population of Scotland is projected to decrease despite recent increases in fertility and an excess of immigrants over emigrants. The reason for the projected decline is the result of prolonged low fertility. The most immediate effect is ageing of the population. The causes and consequences of this demographic profile are discussed. To counter potential negative impacts it is recommend that the pension system be reformed, pension ages raised, healthy living and inclusion in society promoted and migration policies formed to encourage immigration of skilled people and encourage and the return of emigrants.

Key Words: Ageing population, Scotland, consequences and responses.

\section{Résumé}

On a prévu que la population de l'Ecosse va diminuer malgré les augmentations récentes de fertilité et l'excédent des immigrants sur les émigrants. La diminution prévue est le résultat d'une fertilité réduite prolongée. L'effet le plus immédiat est une population vieillissante. Les causes et les conséquences de ce profil démographique sont discutées. Pour contrecarrer les effets négatifs possibles du vieillissement, il est recommandé de réformer le système de pension, d'élever l'âge de départ en retraite, de promouvoir une vie saine et une inclusion sociale, mais aussi de créer une politique de migration encourageant l'immigration des gens manuels et professionels et le retour des émigrants.
\end{abstract}

Mots clefs: Population vieillissante, l'Ecosse, conséquences et réponses 


\section{Introduction}

Many developed countries have become concerned about population ageing at the beginning of the 21 st century. According to the United Nations Population Division (2001), the rate of change caused by the ageing of populations is unprecedented, affecting society in these countries with enduring changes. The main cause of ageing has been prolonged below-replacement fertility rates, which, if the current trends continue, will lead to population decline. The prospects of population ageing and decline affect the vigour and the psyche of a nation and are of great political concern in modern societies.

In this paper we shall tease out the causes of this demographic change and expand on some of the implications. The likelihood of the continuation of the recent demographic trends will be assessed, and some strategies for addressing ageing issues will be pointed out. To do this, we present and review the current situation of Scotland. First a review of population trends in Scotland is presented and a comparison made with other developed nations, then the drivers of demographic change in Scotland will be discussed. In next section, the consequences of demographic change on Scottish society are elucidated and the paper concludes with possible solutions to potential problems arising from population ageing and decline.

\section{Population Trends in Scotland}

The Scottish Registrar General stated in the 2003 Annual Review, that "although the overall population is very similar to what it was 50 years ago at just over 5 million, this apparent stability masks big changes in the age structure and geographical distribution of the population within Scotland" (General Register Office for Scotland [GROS], 2003). The median age of the Scottish population has risen since 1951 from 31 to 38 years and now $10 \%$ of the population is over the age of 71 . In 1951, $10 \%$ of the population was over the age of 64 . According to the Economic and Social Research Council (ESRC, 2004:1) "Between 1995 and 2001 Scotland's population fell by 1 per cent, while the UK population rose by 2.8 per cent and the EU average rose by 2.2 per cent. In this period no other EU country experienced a population decline." The decline is projected to continue well into the middle of this century (see Figure 1). From Figure 1, it is clear that for most developed countries, notably Australia, New Zealand, and Canada, populations will continue to grow whilst the populations of Spain, Germany, Italy, and Scotland are projected to fall.

Although newsworthy, these projected declines are not news. Their causes, however, and more particularly the causes of decline in Scotland, have not been fully determined. A population fall was anticipated (GROS, 2003) as a result of persistent subreplacement fertility, together with an imbalance in migration flows in favour of emigration. However, this has not been the case. Instead, international emigration 


\section{Figure 1. Population Change during 2001-2030 among Selected Developed Countries (Principal Variant Projections)}

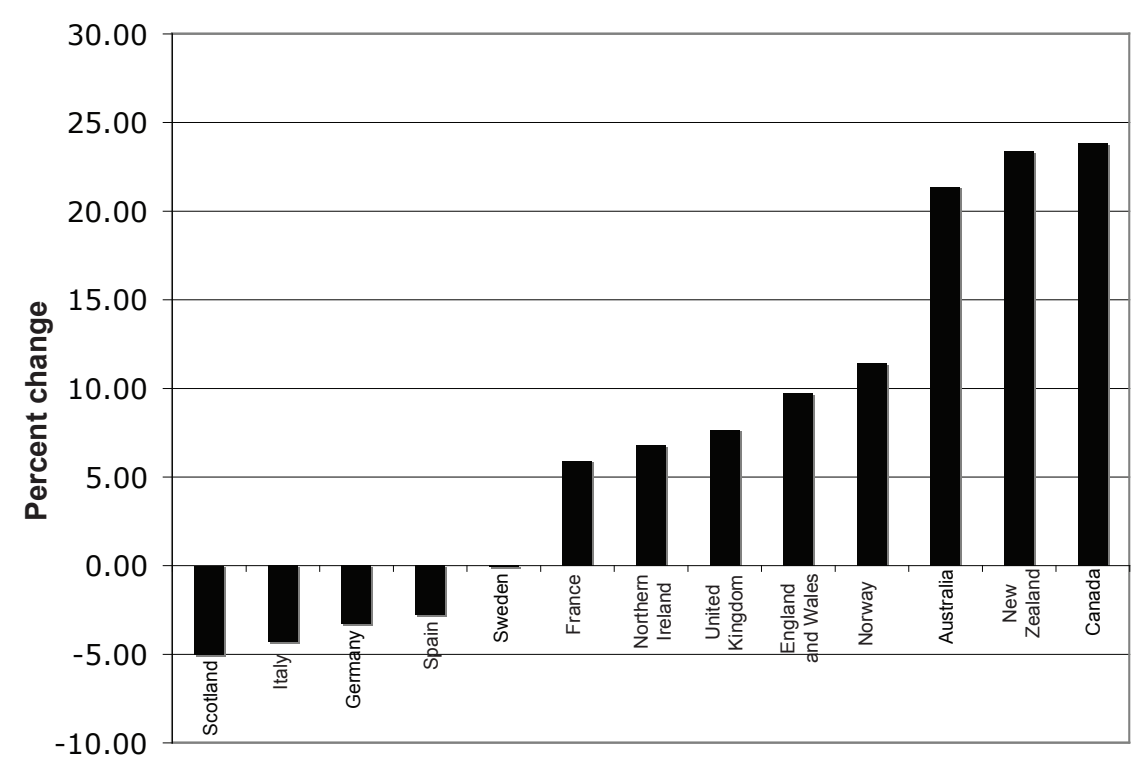

Source: Registrar General's Annual Review, 2003; US Census Bureau (2003).

rates have declined since 1951, but fertility has exhibited a decline to well below replacement rate fertility. The total period fertility rate was at a high of 3.09 in 1964, declined sharply to 1.70 in 1970 , continued a slower decline to 1.48 in 2002 , and rose to 1.67 in 2006. However, in the long term and for principal (or central) variant projection purposes a total fertility rate of 1.6 is assumed by the General Register Office for Scotland (2007).

Over the period 1951 to 1966 there was a net outflow of migrants at around 35,000 per annum. The net out-migration decreased to around zero by 1990 , and, since 2004 , there has been excess immigration of up to 20,000 per annum. The majority of these new migrants are young single immigrants from the recent expansion of the EU. By far the largest proportion of these are Polish, likely because of historical ties between Poland and Scotland. Migration from Scotland to the rest of the UK, particularly to England, is significant and difficult to measure. It has been estimated that in 1998 Scotland experienced a net loss of around 3,800 people to the rest of the UK. These losses are all in the 15-34 age group. There is a net inflow of migrants over the age of 45 years, many of whom are returning to Scotland to retire (Boyle and Graham, 2002; Graham and Boyle, 2003).

It may be noted here that the new initiative of government immigration policy has given talented young people from abroad the chance to live and work in Scotland 
after successfully completing their degree study at Scottish universities (Home Office, 2006). This may have contributed to recent population increase, as well as having a positive impact on the Scottish labour market. However, according to Wilson and Rees (2003), policies favoring immigration can only slow population decline and make little difference to population ageing.

The consequence of the overall sustained fertility decline is an ageing population, and this effect has been compounded by increased life expectancy. Since 1951, life expectancy of Scottish males and females has risen from 64.4 years and 68.7 years respectively to 73.4 for males and 78.8 for females in 2001. It is projected to rise to 79.2 for males and 83.7 for females by 2031 (GROS, 2007). The changing age structure of the Scottish population is illustrated by a comparison of 1971,2001, and the projected 2026 population pyramids, which are displayed in Figure 2. From these pyramids the onset of an ageing society is clearly observed. As Wright (2004:13) warns, these trends contain the threat of "a sizeable reduction in the standard of living of Scottish people." By this, Wright warns of a decline in personal wealth and an increase in social exclusion in Scottish society.

Shown in Figure 3 is the projected median variant percentage change in age structure over the period 2004-2031. This analysis shows that there will be fewer young people than there are now and also that there is a clear ageing trend. This has important implications on the sustainability of the population in that the population of working age will need to become more productive in order to support the growing old dependent population.

In recent years in Scotland there have also been large changes in the geographical distribution of population arising from internal migration. Generally, there has been movement from west to east, with all large cities except Edinburgh showing declines. In Edinburgh, the under 16 year old population has increased by $6.5 \%$ and the population aged 16 and over has decreased by $5.1 \%$ since 1991-2003. In comparison, the same age group in Glasgow city has decreased by $19 \%$, over the same period. Areas around the big cities, and some rural areas, have increased their populations. The pattern of change is illustrated in Figure 4.

If we investigate recent evidence and look at a longer time horizon, 2002-2018, clear percent changes across different regions are evident. As a consequence there is likely to be a dramatic change in future growth rates of the different local authorities as displayed in Figure 5. The larger population centres in the east of Scotland, with the exception of Aberdeen, particularly those round the city of Edinburgh such as East and West Lothian, will continue to grow. On the other hand, the populations to the west of Scotland and in more remote areas are expected to decline. During the period more than $10 \%$ population decline is projected for Eilean Siar, Dundee, Aberdeen, Inverclyde, and Orkney Islands.

Just as there is variation in the distribution of population, there is also a geographical dimension to the age structure of the Scottish population. This is illustrated in the bar chart displayed in Figure 6 from which is apparent that remote areas such 
Figure 2. Population Pyramids for Scotland: 1971, 2001 and 2026 (Projected)

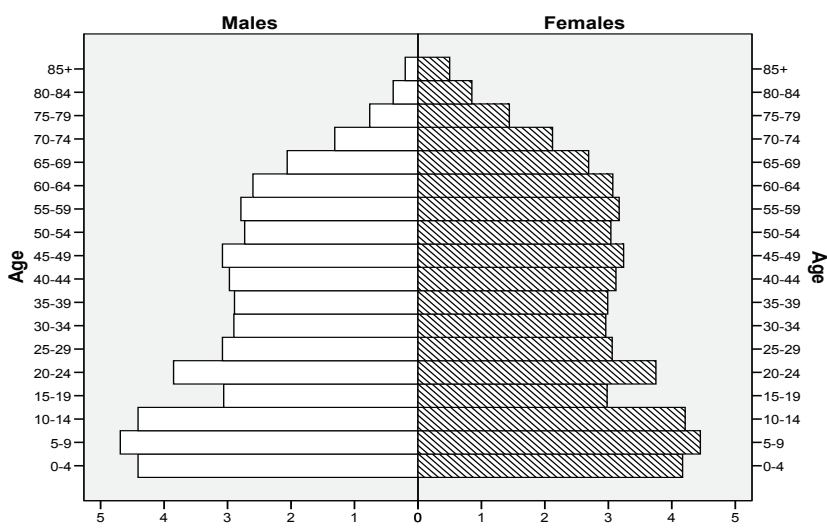

Scottish population pyramid, 1971

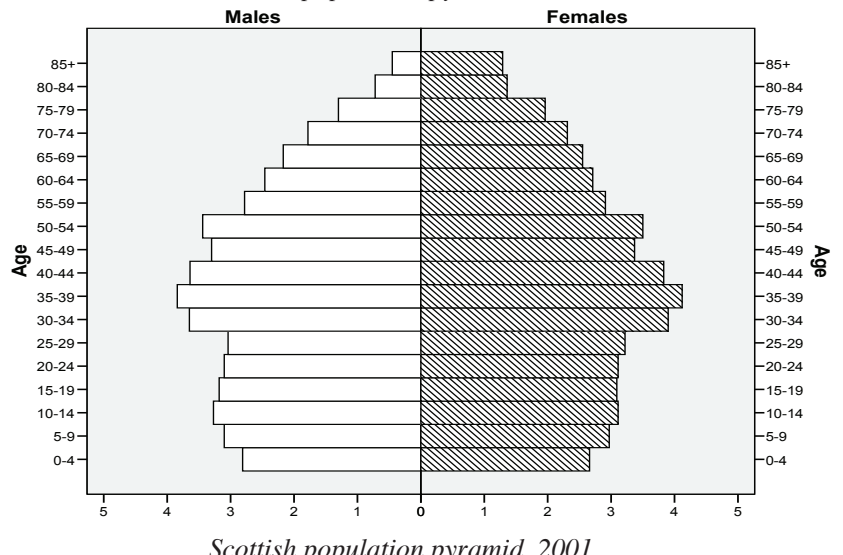

Scottish population pyramid, 2001

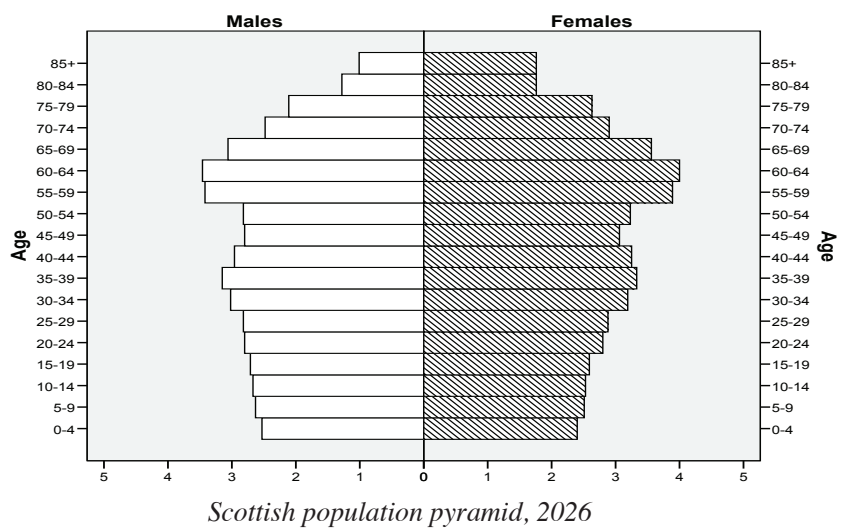

Source: General Registrar of Scotland (GROS, 2003). (principal variant projections) 
Figure 3. Projected Change in the Age Structure of the Scottish Population 2004 to 2031 (Principal Variant Projections)

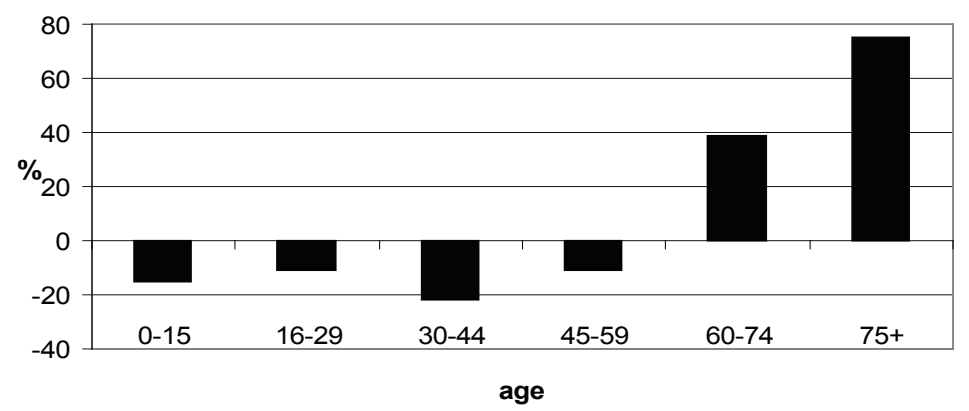

Source: general Registrar of Scotland (GROS, 2007).

Figure 4: Population Change during 1991-2006 in Various Geographical Regions of Scotland

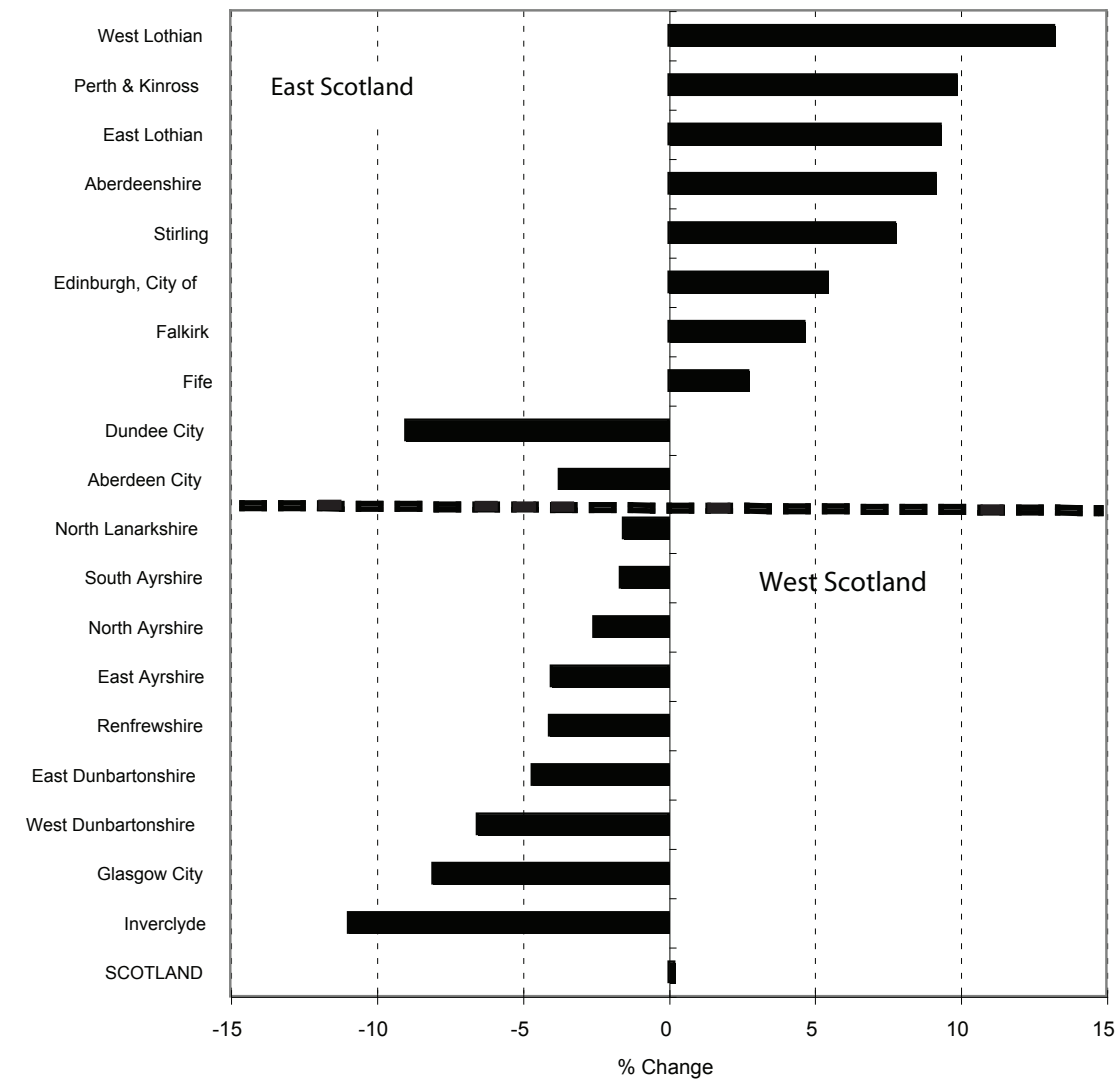

Source: General Registrar of Scotland (GROS, 2007). 
as Eilean Siar, Dumfries, Galloway, and local authorities to the west of Scotland such as Renfrewshire, Inverclyde, and South Ayrshire have an older age profile. In contrast, those authorities located to the east of Scotland such as West Lothian and Aberdeenshire have a younger age profile. Comparing the two major cities, one finds that Glasgow is close to the Scottish average but Edinburgh has fewer people below age 16 and beyond age 64, so has a higher proportion who are in the age group associated with economic activity.

\section{Comparisons with other Developed Countries}

Although economically Scotland appears typical alongside other advanced economies such as France, Ireland, Norway, and England and Wales (see Figure 1), more detailed comparisons reveal a different picture. Scotland, as Table 1 shows, is at the forefront of the ageing phenomenon. In his review of ageing in Europe, Coleman (2001) shows that many European countries will, in the near future, be in a similar position to that of Scotland. From the median variant projections displayed in Table 1, it is clear that the Scottish population is declining but by 2025 the rate of natural decrease is expected to be far more in Spain, Italy, and Germany implying greater negative percentage growth in these countries. It also appears that health is an issue for Scotland as shown by the lower projected increase in life expectancy at birth compared to the comparator countries shown in Table 1 . However, in terms of rates of growth in life expectancy, a $6 \%$ rise over a 25 year period is encouraging and is on a trajectory for improvement to converge to the levels of those countries listed in Table 1. Although life expectancy in Scotland is lower than the other countries in the table, as a result of relatively low populations of young people, the percentage of the Scottish population over the age of 60 is currently above the median of the countries in Table 1 and is expected to remain above the median in 2025. It is of concern to

Table 1. Comparison of Demographic Trends in Selected Developed Countries

\begin{tabular}{|c|c|c|c|c|c|c|c|c|c|c|c|c|c|c|}
\hline \multirow{3}{*}{$\begin{array}{l}\text { Country/ } \\
\text { Territory }\end{array}$} & \multirow{2}{*}{\multicolumn{2}{|c|}{$\begin{array}{c}\text { Rate of } \\
\text { natural in- } \\
\text { crease }(\%)\end{array}$}} & \multirow{2}{*}{\multicolumn{2}{|c|}{$\begin{array}{l}\text { Annual rate } \\
\text { of population } \\
\text { growth }(\%)\end{array}$}} & \multirow{2}{*}{\multicolumn{2}{|c|}{$\begin{array}{l}\text { Total fer- } \\
\text { tility rate }\end{array}$}} & \multirow{2}{*}{\multicolumn{2}{|c|}{$\begin{array}{c}\text { Life } \\
\text { expectancy } \\
\text { at birth }\end{array}$}} & \multicolumn{6}{|c|}{ Percentage of population over 60 years } \\
\hline & & & & & & & & & & 2000 & & $\begin{array}{r}202 \\
\text { varia } \\
\end{array}$ & $\begin{array}{l}5 \text { (prin } \\
\text { nt proje }\end{array}$ & $\begin{array}{l}\text { acipal } \\
\text { ections) } \\
\end{array}$ \\
\hline & 2000 & 2025 & 2000 & 2025 & 2000 & 2025 & 2000 & 2025 & Total & l Male & Female & Total & Male & Female \\
\hline Scotland & -0.11 & -0.15 & 0.1 & -1.4 & 1.48 & 1.6 & 75.5 & 80.0 & 21.0 & 9.0 & 12.0 & 30.0 & 13.4 & 16.6 \\
\hline $\begin{array}{l}\text { United } \\
\text { Kingdom }\end{array}$ & 0.1 & 0.0 & 0.4 & 0.2 & 1.7 & 1.7 & 77.8 & 81.1 & 20.4 & 8.8 & 11.2 & 27.4 & 12.5 & 14.9 \\
\hline France & 0.4 & 0.0 & 0.5 & 0.1 & 1.9 & 1.8 & 78.8 & 81.8 & 20.5 & 8.6 & 11.9 & 28.4 & 12.4 & 16.0 \\
\hline Germany & -0.1 & -0.5 & 0.1 & -0.2 & 1.4 & 1.5 & 78.1 & 81.2 & 23.2 & 9.5 & 13.7 & 32.9 & 14.8 & 18.1 \\
\hline Sweden & -0.1 & -0.2 & 0.0 & -0.1 & 1. & 1.6 & 79.6 & 82.2 & 22.1 & 9.6 & 12.5 & 30.3 & 13.8 & 16.5 \\
\hline Norway & 0.3 & 0.1 & 0.5 & 0.3 & 1.8 & 1.8 & 78.6 & 81.7 & 19.3 & 8.3 & 11.0 & 26.8 & 12.2 & 14.6 \\
\hline Spain & 0.1 & -0.4 & 0.2 & -0.3 & 1.2 & 1.5 & 79.1 & 81.8 & 21.7 & 9.3 & 12.4 & 30.0 & 13.2 & 16.8 \\
\hline Italy & 0.0 & -0.5 & 0.3 & -0.3 & 1.2 & 1.5 & 79.1 & 81.9 & 23.8 & 10.1 & 13.7 & 32.5 & 14.4 & 18.1 \\
\hline Canada & 0.4 & 0.1 & 1.0 & 0.6 & 1.6 & 1.7 & 79.1 & 82.2 & 16.7 & 7.3 & 9.4 & 27.7 & 12.5 & 15.2 \\
\hline $\begin{array}{l}\text { New } \\
\text { Zealand }\end{array}$ & 0.7 & 0.3 & 1.2 & 0.5 & 1.8 & 1.8 & 77.8 & 81.2 & 15.4 & 6.8 & 8.6 & 21.8 & 9.8 & 12.0 \\
\hline Australia & 0.6 & 0.2 & 1.0 & 0.5 & 1.8 & 1.7 & 79.8 & 82.3 & 16.4 & 7.4 & 9.0 & 25.6 & 11.7 & 13.9 \\
\hline
\end{tabular}

Source: US Census Bureau (2003), 2004 Projected Population of Scotland, Variant Projections Registrar General for Scotland 
Figure 5. Percentage Change in Scottish Local Authority Populations Based on 2002 Projections of the Population in 2018 (Principal Variant Projections)

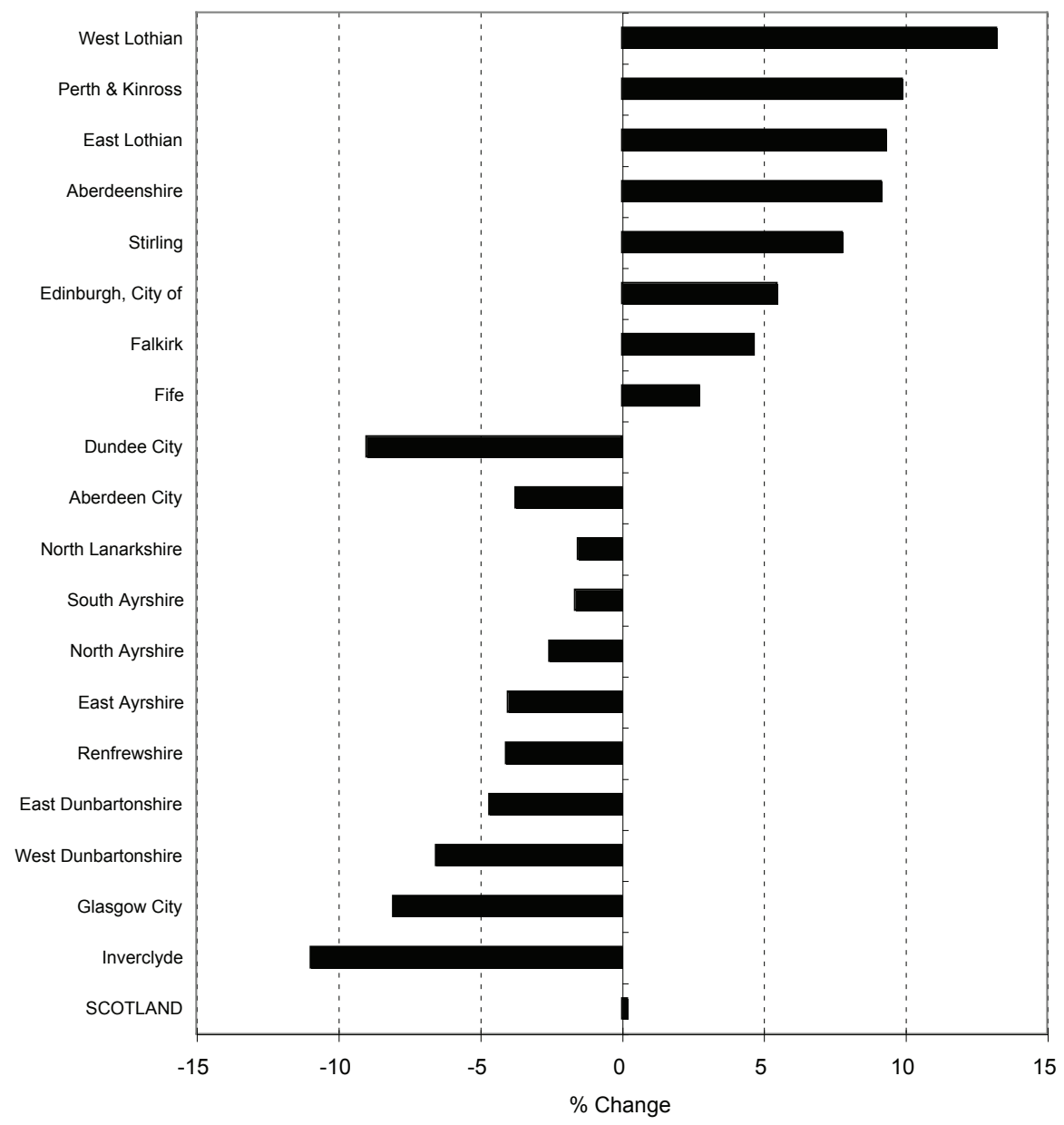

political leaders that the proportion of the population drop over the next 20 years in Scotland is expected to be far higher than comparator countries.

\section{The Drivers of Population Ageing and Decline}

As societies become more affluent and developed, their fertility falls. Bongaarts and Watkins (1996) relate these changes to general development via the Human Development Index, which is a composite of GDP per capita, life expectancy at birth, and literacy rates. They argue that there is a mutual reinforcing of fertility trends amongst countries of similar social, belief, and cultural systems, and from this a social norm 
Figure 6. Percentage of the Population between 0 and 15 Years and 65 and over Years for Scottish Local Authorities in 2001

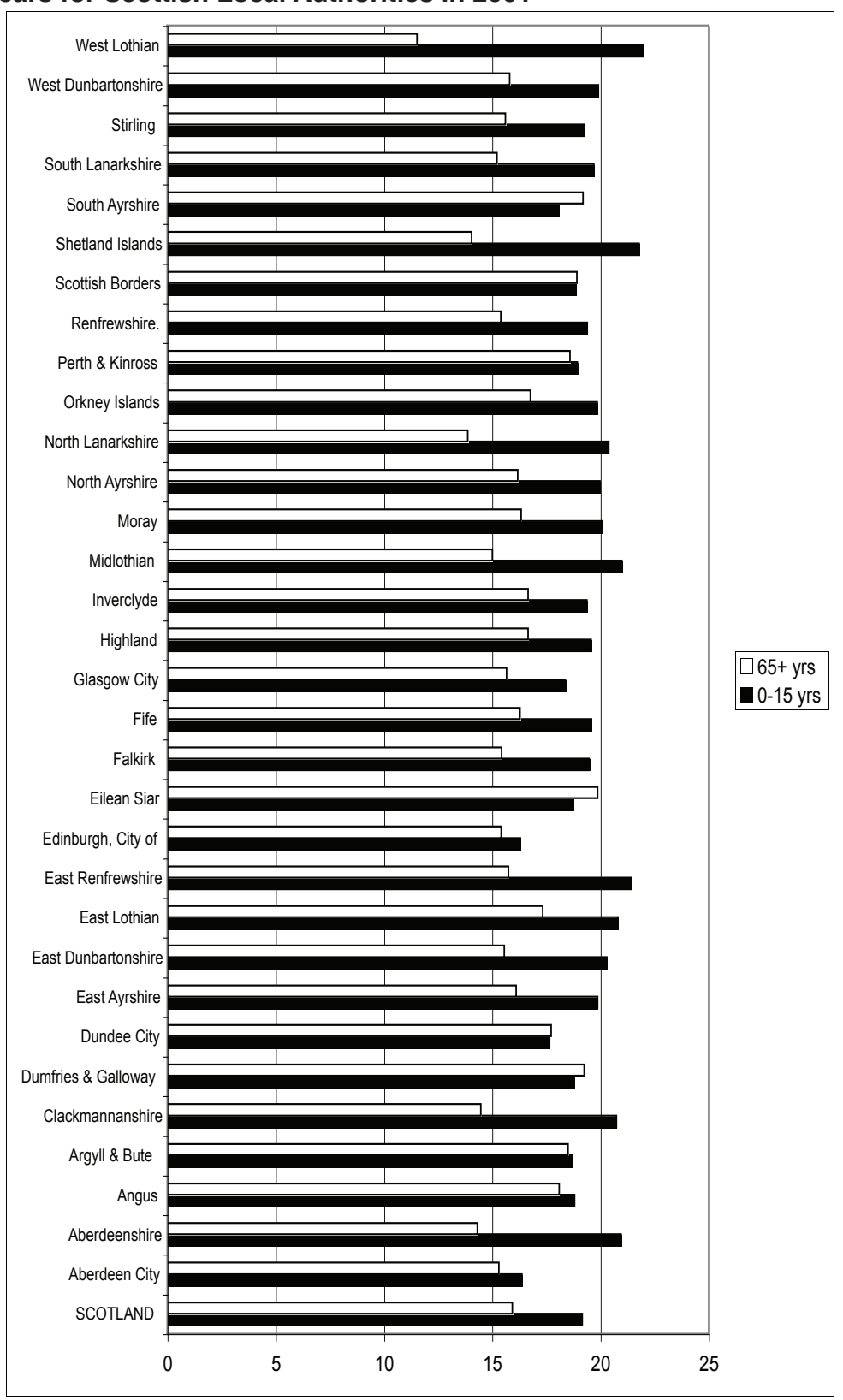

Source: General Registrar of Scotland (GROS, 2003) 
related to fertility is established. In Europe, a social norm has become established which runs contrary to large families, and marriage dissolution is socially acceptable. In these countries, more hedonistic lifestyles and increased affluence have created expectations of a society typified by conspicuous consumption, making small families difficult to resist. This has led to a popular culture bolstered by ever more intrusive media portraying a lifestyle devoid of children. Children inhibit expectation fulfilment, not just for the cost of goods but in the sense of opportunity costs, since children take up time otherwise available for the social activities implied by a consumer society. For a more detailed argument see the works of Becker (1965), Ermisch $(1982 ; 1995)$ and Joshi and Overton (1984).

As women have gained more autonomy and independence in society, they have engaged more in the workforce. This has boosted consumption, and contributed to the delay of marriage, the reduction of marriage rates, and the reduction in fertility. Increased affluence increases expectations and, in times of economic slowdown, it becomes even more difficult to justify a career break for child rearing. The impact of these widespread social changes has been compounded (in Scotland as elsewhere) by changing patterns of work. The replacement of unskilled work by career patterns which increase the importance attached both to prolonged periods of training and to an unbroken period of employment to gain experience and skills has further strengthened the tendency to delay childbearing.

One aspect of the consumption culture that is especially striking in Scotland is the rise in home ownership over the last 30 years. In the 1970s, the majority of people in Scotland lived in houses rented from the local council or charitable agencies (social housing), but no longer. In 1979, 54.1\% of the population were living in "social housing," but by 1998 this had fallen to $26.4 \%$, while the home owning sector grew from $35.2 \%$ to $61 \%$ over the same period. The struggle to raise the initial deposit and then meet mortgage payments may well be acting to delay the onset of childbearing. In some of the growing areas of Scotland, notably Edinburgh, where the population has been swelled by migration, housing shortages have, until recently, led to large and sustained increases in house prices. This has almost certainly exerted a significant downward pressure on fertility. To this must be added the direct and indirect costs of childrearing for parents, which according to Apps and Rees (2001), in a modern society represent a very large proportion of household consumption.

Another dimension to population ageing in Scotland is increased longevity, i.e., people are living longer. GROS (2007) reports that since 1981 life expectancy at birth has risen from 69.1 years for males and 75.4 years for females to 74.8 years for males and 79.7 for females. Scotland does not compare well with OECD countries. The average male and female life expectancies at birth of these countries in 2005 were 75.7 years for males and 81.4 years for females (Organization for Economic Co-operation and Development [OECD], 2007). Hence, there is opportunity for further improvement, and there are health campaigns to do this through improving the housing stock, diet, lifestyle, and reduction of smoking (see Blades, 2004; National 
Health Service [NHS], 2001). In March 2006, smoking was banned in public enclosed spaces.

As discussed in the introduction, changes in migration have also contributed to population ageing. The main component of immigration is economic migrants of working age, who either do not have children or leave their children in the care of family members in their native countries. The other major component of immigration is those returning to Scotland as they approach retirement. Part of the return migrations in later life are due to a revolutionary positive public policy decision taken by the Scottish Executive to provide personal care free of charges for all older people under the NHS which is an unique example in modern time (Ormston and Curtice, 2007).

\section{Consequences of Population Ageing}

Population ageing in Scotland will increase the relative size of the dependent population, creating a potential increased "burden" on public pension provision and health care. Figure 7 charts the changes in the ratio of those aged 15-59 years to those of pension age (taken as over 60 years), which we label the elderly support ratio, and in the ratio of $0-14$ years to those over 60 years (the young-old ratio), since 1951 . Clearly the ratios decrease as the population ages. One potential outcome of these trends is an increasing tax burden for those in the main productive age groups.

As people age, general health deteriorates; the implications for health costs have been demonstrated by MacDonald et al. (2001) and Wood and Bain (2001), particularly with reference to an increasing number of older females living alone. As an example of the increasing demands for health care from older groups, Wood and Bain report that males aged 65-75 years consult their general practitioners $66 \%$ more than those aged 45-54 years, and the cost of prescriptions for males aged 65-75 are more than double those for males aged 45-64 (Wood and Bain, 2001:61).

The prospect of a demographic crisis has, however, been questioned in Scotland

\section{Figure 7: Percent Changes in the Elderly Dependency Ratio}

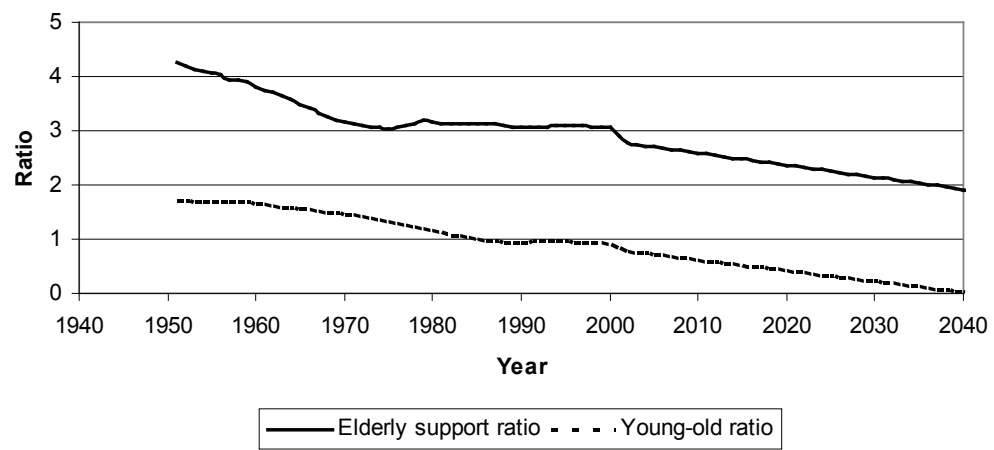


by Shaw (2002:4), who suggests that the impression of crisis has coincided

... with the tendency to marginalize the elderly from the labour market and from society at large.... The real issue is not so much the fact that there are not enough people capable of working to support an elderly population. Rather increasingly older people find it difficult to find employment.

The employment of older people has decreased more than any other age group, and as a consequence over one-third of men between 50-65 are now jobless in Scotland (Labour Force Survey, 2006). The UK and Scottish Governments via the Department of Work and Pensions (DWP, 2007) have responded to pressures arising from the ageing population by reducing the qualifying period for receipt of full state pension; they plan to raise the state pension age to 68 years for both men and women after 2024. These reforms will ensure compliance with the European Union's Equal Treatment Directive.

Shaw also questions the fears for an increased health burden. People in Scotland are getting healthier: those who are currently below the age of fifty have been brought up in a more health conscious society, diet and housing have improved, and generally there has been a sizeable reduction in smoking, although high smoking levels persist amongst young women. Scotland's urban environment has improved enormously since the mid 1970s with the enforcement of smokeless fuels. Scottish people are expected to live longer, healthier lives, which may also lead to longer working lives. If this is so, then the increase in both the pension burden and the demand on health services should be much less than suggested by some of the more pessimistic projections. The growing market for treatments and drugs associated with old age might have the effect of lowering the costs of health inputs. Technological innovation in health provision should also have a positive impact in lower treatment costs and durations. This does not mean that one should not be concerned about the ageing Scottish population. The sheer number of people in the older age groups will mean that access to healthcare and pensions are likely to be a major problem. A particular concern is the gap between the poor and the affluent. Social exclusion is a feature of several urban and rural areas of Scotland, particularly amongst the old. The value of pensions received among the affluent have grown much more than those of the poor. Falkingham (2002) illustrates this "rising inequality" in the median net income of pensioner couples over the period 1979 to 1996-7. She observes that people in the top income quintile have seen their earnings rise much more than those in the lower quintiles. Those pensioners in the top quintile have experienced a doubling of income while those in the bottom quintile have only experienced around a $40 \%$ rise in income.

From analysis of the Scottish Household Survey, MacDonald et al. (2001) show that fewer than half of pensioner households are in receipt of an occupational pension, and as Vincent (1996) has pointed out, those who have made their own provision have often received significantly less pension than they had expected and have complained about receiving poor advice. Thus a possible consequence of population 
ageing is an increasingly divided society. This will also manifest itself in gender imbalances, as proportions of older women increase more rapidly than men. Currently the ratio of women to men over the age of 75 years is 1.86, i.e., almost 2:1 (for further discussion, see Henrard, 1996). One concern in relation to this sex imbalance among the old is highlighted by MacDonald et al. (2001) who state that low reported income is most common amongst lone Scottish women over the age of 75 .

The supply of education will clearly be affected. The education sector is a major employer in Scotland, so there are serious economic consequences to the reduction in the population of young people. Already there have been closures and mergers of primary schools. In 1981 there were 2,418 primary schools; in 2006 the number was reduced to 2,184 . As the number of young decreases, the effect seen in primary schools will ripple through the educational system. Currently there are twelve universities in Scotland serving a standard university aged population of 316,500 of whom around $50 \%$ enter higher education. By 2020, this age group is projected to fall to 258,000 . Universities are facing pressure to change their markets. There is talk of mergers, universities are embracing life-long learning as part of their main activities, and have entered the global market for education both in delivering educational programs overseas and attracting students from beyond the EU to programs delivered in Scotland. In terms of public spending, reduced expenditure on education might help to offset increased health spending, however, there will be large adjustment costs. Also, supplying education and health to depopulating regions will make benefits from economies of scale difficult to achieve.

The implications of population ageing for Scotland's educational system may be seen as part of a more general economic malaise. The public sector currently employs some 585,600 people (23.8\% of the total Scottish workforce), but as the population reduces so will the requirement for the number of public servants (Hughes and McPhee, 2006). As the population shrinks, so will the domestic market for homeproduced consumption goods, and the revenue that has been generated from these markets. Scottish companies will increasingly have to look to worldwide markets at a time when emerging nations with lower production costs provide fierce competition. Meanwhile, those who have invested in private pension schemes to top up company and state pensions have seen the value of their funds diminish as a result of stock market falls. Overall, Scotland's situation in respect of economic consequences of ageing in a global context is likely to be similar to other developed countries, as described in a recent OECD report (Turner et al., 1998).

The ageing population will also have profound influences on transport. Car ownership is increasing, and the drift to urban centres has increased congestion. Edinburgh council has considered introducing a congestion charge, reflecting wider policy initiatives to divert people from car use to public transport. The public system will need substantial investment and redesign to meet the requirements of an aged population. Older people already do not fare well in access to transport. As MacDonald et al. (2001) report, 37\% of men and 59\% of women aged over 65 do not 
have a car. Similarly, the housing stock needs overhauling and more single or double unit houses constructed with ensured ease of access (Wood and Bain, 2001). Recent electoral patterns suggest that older generations will come to dominate politics even more than they already do. There has been a worrying downward trend of participation in elections amongst the young. Less than half the eligible electorate voted in $2003-49 \%$, down from 59\% in 1999. Clarke et al. (2002) demonstrate that in 2001 the "sense of civic duty" amongst those over 65 was more than double that of the 18-25 age group. Whether low participation and civic responsibility stick throughout the lifetime of the currently young is a worrying question, but nevertheless the young may well have proportionately less power in the political arena.

An ageing, and then declining, population will make Scotland less vigorous, restricting economic growth. Perhaps Julian Simon's (1981) rather outspoken view that countries with growing populations are more dynamic and innovative than those with declining populations is right. There are, however, some positive outcomes from population ageing: there will be less need for high-density living, more flexible working conditions may develop, and crime rates will decline (as will, hopefully, the prison population) as the number of young males is reduced.

\section{Possible Solutions to Potential Problems Associated with Population Ageing and Decline}

The policy challenges of population ageing have been a focus of the UK's Foresight program, which recommended, among other things, that older people take a more active part in the governance of the country (Dunnell, 2000). Issues raised include aspects of labour force participation, leisure and learning, finance, healthcare, infrastructure design for living, and the use of information communication technology. Improvements in these fields presuppose increased deployment of capital that will allow economic growth to continue and provide support for the dependent population. Young (2002), for example, is far from pessimistic about population ageing, arguing that standards of living as measured by GDP will double over the next 50 years, enabling transfers of wealth in the form of voluntary bequests from an increasingly wealthy older population to their less numerous children. Young also demonstrates that those over 70 have the highest saving rates as a proportion of household income, and that this has increased since 1974. The UN's Economics for Europe states that there is a need for western economies to promote "equitable and sustainable economic growth in response to population ageing" (UN, 2002:5). Though, as the Economic and Social Council of the UN warns, "growth in itself will not be sufficient to address the distributional issues raised by population ageing, nor indeed is there any guarantee that growth will lead to socially acceptable outcomes" (UN, 2002:3).

The Economic Commission for Europe argues that there is a need to "ensure full integration and participation of older persons in society" and "to promote a positive image of ageing and older persons, particularly of older women" (UN, 2002:2, 3). 
If the old are to take an active part in all aspects of society, there is a corresponding need to combat all aspects of ageism (Jefferys, 1996). Such changes would allow participation in the workforce (and hence relieve the pension burden) only if barriers to labour markets for older workers are removed and their employability improves. However, as Taylor and Walker (1998) discuss, potential employers and the old themselves have considerable attitudinal barriers to overcome, as the percentage work participation of those over 55 has fallen continuously since 1951. In addition, active provision and participation in lifelong learning will be necessary. Davey (2002) gives an example from New Zealand, which shows that participation in formal education enhances the skills of older people and promotes "active ageing." Active ageing means that increased knowledge and cultural awareness equips older age groups to participate in modern economies and develop their own worth.

Building on the recommendations of the UK Foresight program (Dunnell, 2001), possible solutions to the problem of ageing can be summarized in five broad initiatives:

1. Increase elderly participation, in the workforce and the community, by promoting a more positive image of older people, ensuring that they have suitable skills, making work more flexible, and lowering barriers to those re-entering work.

2. Promotion of healthy living by adapting physical and transport infrastructures to allow independent living and increasing the number of public carers, as extended family networks decrease. Older people should expect to take charge of their lives during increasingly long and healthy active lifetimes.

3. Governments must highlight the need for improved financial planning for retirement, promote public/private partnerships, and increase the retirement age. For many, much of their individual resources are held in property; as they withdraw from the labour market they need ways of releasing this capital. Baroni (2007) discusses the future of pensions in detail and the need to move from "pay as you go" to private and individual schemes. More importantly, it is essential to consider the holistic nature of the variables which affect the pension system.

4. Promotion of the inclusion of older people in society to ensure that they are not disenfranchised in social and economic planning. Lifelong learning will increase their participation, but steps are needed to ensure that poorer elderly people from lower social classes can participate in society. In particular, there is a need to improve the health of the least well off. Bernard and Phillips (2000) argue that an inclusive government policy is required to address the "diversity of needs of an ageing population." However, ageism is a barrier to be faced and Minichiello et al. (2000) argue that including older people in society requires overcoming many negative views. In forming these policies it will be important to address the regional dimension of ageing and depopulation. Some areas of the country will depopulate, fuelled by economic motives for migration; in these regions, ageing will appear more pronounced. Hence, in policy formation inclusion of 
these regions must be stressed.

5. Promotion of the image of Scotland overseas, reducing barriers to potential immigrants who can contribute to Scottish society and culture. The Scottish government has placed much emphasis on this, in particular promoting the "Fresh Talent Initiative." This allows foreign students who have graduated from degree and masters programs to remain in Scotland for a further two years to find work and become established in the country (Home Office, 2006). However, Wright (2004) points out that to base a policy on immigration is very difficult, especially when control remains with the UK government, and expresses skepticism of this instrument being successful. The UK government resists relaxing immigration policy, perceiving migration to Scotland as a backdoor to the stronger English economy. A regional policy on migration must be developed to ensure that the areas in Scotland where the populations are ageing fastest receive benefits from immigration.

The devolved Scottish parliament, whose civil servants form the Scottish Executive, now renamed the Scottish Government, has responded to the challenges raised by an ageing and potentially declining population by forming most of the above into a strategy for Scotland's future (see Scottish Executive, 2007). Currently £5.1 billion per annum (5.9\% of Scottish Gross Domestic Product) is committed for those over the age of 60 years. This is targeted to allow older people remain in their own homes; via a free program some 50,000 people receive personal care at home. Those over 60 years benefit from free bus travel anywhere in Scotland and travel demand responsive services are provided such as "dial-a-ride" and "dial-a-bus." Spending is directed to improve heating in older people's houses and ensure that fuel poverty is prevented. Improving health is a key element of the current strategy; highlights are banning smoking in public places since March 2006, promotion of physical activity, free eye examinations, and a falls prevention initiative. Other important elements of the current policy for ageing Scotland are a lifelong learning strategy, a digital inclusion strategy, initiatives to promote employability such as Workforce Plus (see Scottish Executive, 2006) and promotion of community service by programs such as the Retired and Senior Volunteer Program and the National Forum on older volunteering in Scotland. The Scottish government provides $£ 200,000$ per annum to support a telephone helpline for older people. For further details see Volume 2 of the Scottish Executives strategy document "All Our Futures."

The aim of the Scottish government is to build on this current strategy by establishing a National Forum on Ageing to champion strategies directed to the ageing population, and then to develop the current strategy in six priority areas. These areas are: continued improvement of access and opportunities for older people to participate in all activities in society; better links between the generations; continued improvement in the health and quality of life of older people; improved care, support, and protection for older people; creation of an appropriate infrastructure for older 
people. These are taking effect, and the Scottish government's vision of Scotland as "a place where ageing is more than accommodated, it is welcomed, supported and turned to advantage" (Scottish Executive, 2007), may be realized.

\section{Conclusions}

Scotland's population is ageing and, despite recent increases in the number of people living in Scotland and in fertility, the population of Scotland is projected to decline. There are concerns that this will be detrimental to the Scottish economy and the well being of the people living in Scotland. The changes to the age structure are not uniform; this, coupled with internal migration, has led to particularly acute decline in the west and some of the larger cities in Scotland. The east, especially around the city of Edinburgh, the home of Scotland's devolved parliament, appears to be benefiting from a net inflow of younger people. The situation of ageing and projected decline has arisen mainly as a result of prolonged subreplacement fertility rather than, as speculated in the 1970s, an imbalance of immigration in favour of emigration. In the last few years, there have been more immigrants than emigrants, though emigration to England remains significant. The immigrants are principally either former emigrants returning or from the recent European Union accession countries particularly Poland, often labelled as economic migrants.

Scotland's devolved government is concerned that these demographic changes will lead to increased social exclusion, an effect that will be more evident in some areas of the country than others. As a consequence, the Scottish government has formed and implemented a strategy to ensure that ageing and decline do not result in enduring negative effects but can be turned to an advantage. Key tenets of this strategy are to create a positive image of the old, foster intergenerational exchange, ensure inclusion in society by promoting participation in the workforce, the use and access of information and communications technology, participation in lifelong learning, the reduction of poverty, and the improvement of the health and mobility of the old. Volunteering is promoted to involve the old more in their community. Although expensive, there are signs that the strategy is effective. Immigration is also encouraged but this may not be an effective long-term strategy, especially when other European countries such as Italy and Germany relax their immigration policies to allow younger labour into their workforces.

As other European countries age - notably Italy, Spain, and Germany - they should pay attention to the strategy implemented by the Scottish government. By monitoring this strategy they will learn much which will help counter the potential negative effects of ageing in a population.

\section{Acknowledgements}

This paper benefited from an oral presentation at the Canadian Population Society (CPS) annual meetings held at Dalhousie University, Halifax, Nova Scotia, during 
June 3-5, 2003. Authors wish to express their gratitude to Philip Kreager and Kenneth Howse for making valuable suggestions on an earlier version of the manuscript before it was accepted as Oxford Institute of Ageing Working Paper \#207 (http:// www.ageing.ox.ac.uk/workingpapers.html). Finally, we thank the two anonymous reviewers of Canadian Studies in Population for their valuable comments and suggestions. The views expressed herein are those of the authors and they are responsible for any errors and mistakes.

\section{References}

Apps, P. and R. Rees. 2001. "Household production, full consumption and the costs of children." Labour Economics 8(6):621-648.

Baroni, E. 2007. Pension Systems and Pension Reform in an Aging Society: An Introduction to the Debate. Copenhagen: Institute for Future Studies, Arbetsrapport/Institutet för Framtidsstudier.

Becker, G.S. 1965. “A theory of the allocation of time.” The Economic Journal 75:493-517.

Bernard, M. and J. Phillips. 2000. "The challenge of ageing in tomorrow's Britain.” Ageing and Society 20:33-54.

Blades, M. 2004. "An examination of data on the Scottish diet." Nutrition \& Food Science_34(6):246252.

Bongaarts, J. and S.C. Watkins. 1996. "Social interactions and contemporary fertility transitions." Population \& Development Review 22(4):639-682.

Boyle, P. and E. Graham. 2002. "Does Scotland need a population policy?" Holyrood 25.

Clarke, H.D., D. Sanders, M.C. Stewart, and P.F. Whiteley. 2002. “Britain (not) at the polls, 2001.” http:// www.essex.ac.uk/bes/Papers/pollsrev.pdf.

Coleman, D.A. 2001. "Population ageing: An unavoidable future." Social Biology and Human Affairs 66(1):1-11.

Davey, J.A. 2002. “Active ageing and education in mid and later life." Ageing and Society 22:95-113.

Dunnell, K. 2000. "Policy responses to population ageing and population decline." United Kingdom, expert meeting on policy responses to population ageing and population decline, Population Division, Department of Economic and Social Affairs, UN, New York, 16-18 October.

2001. "Policy response to population ageing and population decline in the United Kingdom." Population Trends 103:47-52.

Department of Work and Pensions (DWP). 2007. Pension Reform 2010 Onwards. London: Department of Work and Pensions, http://dwp.gov.uk/pensionsreform/

Economic and Social Research Council (ESCR). 2004. "The demographic trends in Scotland: A shrinking and ageing population.” ESRC Seminar Series Mapping the Public Policy Landscape, Economic \& Social Science Research Council, http://www.esrc.ac.uk/ESRCInfoCentre/Images/ESRC\%20 Demography\%20Brochure\%20(2) tcm6-17240.pdf.

Ermisch, J. 1982. Economic Models of Period Fertility in Britain. London: Policy Studies Institute.

1995. "Demographic development and European labour markets." Scottish Journal of Political Economy 42(3):331-346. 
Falkingham, J. 2002. Planning Pensions for the $21^{\text {st }}$ Century: Meeting the Challenges of an Ageing Society, Ageing Population - Benefit or Burden. ESRC Conference, Edinburgh, January.

Graham, E. and P. Boyle. 2003. "Scotland's demographic regime: Population and the policies of devolution.” Scottish Geographical Journal 119(4):361-382.

General Register Office for Scotland (GROS). 2003. Scotland's Population 2001 - The Registrar General's Annual Review of Demographic Trends. Edinburgh: General Register Office for Scotland.

2007. Scotland's Population 2006 - The Registrar General's Annual Review of Demographic Trends. Edinburgh: General Register Office for Scotland.

Henrard, J.C. 1996. "Cultural problems of ageing especially regarding gender and intergenerational equity." Social Science and Medicine 43(5):667-680.

Home Office. 2006. Fresh Talent: Working in Scotland Scheme. http://www.workingintheuk.gov.uk/ working in the uk.

Hughes, M. and D. McPhee. 2006. Public Sector Employment in Scotland, Scottish Executive. http:// www.scotland.gov.uk/Publications/2006/11/28151648/6.

Jefferys, M. 1996. "Cultural aspects of ageing: Gender and inter-generational issues." Social Science and Medicine 43(5):681-687.

Joshi, H. and E. Overton. 1984. The Female Labour Force in Britain 1971-1991. London: CPS Research Paper, No. 84-1.

Labour Force Survey. 2006. London: Office for National Statistics.

MacDonald, C., H. Storkey, and G. Raab. 2001. Older People in Scotland: Results from the First Year of the Scottish Household Survey. Edinburgh: Scottish Executive Central Research Unit.

Minichiello, V., J. Browne and H. Kendig. 2000. "Perceptions and consequences of ageism: Views of older people.” Ageing and Society 20:253-278.

National Health Service (NHS). 2001. Health in Scotland 2000. NHS publications, http://www.sehd. scot.nhs.uk/publications/his0/his0-00.htm

Organisation for Economic Co-operation and Development (OECD). 2007. OECD Health Data - Frequently Asked Questions. http://www.oecd.org

Ormston, R. and J. Curtice. 2007. "Different policies, different priorities? Comparing public attitudes to personal care and patient choice in England and Scotland. Research findings." Edinburgh: Scottish Centre for Social Research, March www.scotcen.org.uk.

Scottish Executive. 2006. Workforce Plus - An Employability Framework For Scotland. Edinburgh: Scottish Executive.

2007. All Our Futures; Planning for Scotland with an Ageing Population, Vol. 1 and 2. Edinburgh: Scottish Executive.

Shaw, F. 2002. "Is the ageing population the problem it is made out to be?" Foresight 4(3):4-11.

Simon, J.L. 1981. The Ultimate Resource. Princeton, NJ: Princeton University Press.

Taylor, P. and A. Walker. 1998. "Employers and older workers: Attitudes and employment practices." Ageing and Society 18:641-658.

Turner, D., C. Giorno, A. De Serres, A. Vourc'h and P. Richardson. 1998. The Macroeconomic Implications of Ageing in a Global Context. Economics Department Working Papers No. 193, OECD, 
France.

United Nations Population Division. 2001. World Population Ageing 1950-2050. New York: United Nations.

United Nations. 2002. Population Headliners. No. 290, Bangkok: ESCAP, September-October.

US Census Bureau. 2003. International Database, IDB, United States Department of Commerce, www. census.gov/ipc/www/idbsum.html

Vincent, J. 1996. "Who’s afraid of an ageing population?” Critical Social Policy 47(16):3-26.

Wilson, T. and P. Rees. 2003. "Why Scotland needs more than just a new migration policy." Scottish Geographical Journal 119(3):191-208.

Wood, R. and M. Bain. 2001. The Health and Well-being of Older People in Scotland. Edinburgh: Information and Statistics Division.

Wright, R.E. 2004. Population Ageing and Immigration Policy. Stirling: Scotecon. http://www.scotecon. net/publications/Wright\%20Immigration.pdf.

Young, G. 2002. The Implications of an Ageing Population for the UK Economy. London: Bank of England Working Paper, Bank of England. 